\title{
EPIDENDRUM LASIOSTACHYUM (ORCHIDACEAE): A NEW COLOMBIAN SPECIES OF THE EPIDENDRUM MACROSTACHYUM GROUP
}

\author{
Eric Hágsater ${ }^{1,3}$, Elizabeth Santiago Ayala ${ }^{1,3}$ \& Lizeth Rodríguez-Martínez ${ }^{2}$ \\ ${ }^{1}$ Herbario AMO, Montañas Calizas 490, México, CDMX 11000, México \\ ${ }^{2}$ Facultad de Ciencias Agropecuarias, Universidad Nacional de Colombia-sede Palmira, \\ Cra. 32\#12-00, Chapinero, Palmira, Colombia. \\ ${ }^{3}$ Authors for correspondence: herbamo@prodigy.net.mx • www.herbarioamo.org
}

\begin{abstract}
In Epidendrum, considered a monophyletic genus, diverse groups can be recognized by their similar vegetative and floral characteristics. The revision of one of these groups, the E. macrostachyum group, recognized by the monopodial habit, with sub-apical branching, apical, erect inflorescence, non-resupinate, fleshy flowers, and entire lip, embracing the column, pubescent at least at the base, has led to the description of several new species, including a new species from Colombia that is here described and illustrated. The species is similar to Epidendrum microrigidiflorum, but differs in the inflorescence (distichous, 6 flowered vs. racemose, 8-16 flowered), the shape (trullate vs. widely rhombic) and ornamentation of the lip (sericeous vs. minutely papillose), and the lack of calli on the disc of the lip (ecallose vs. bicallose). In addition, a key to the 41 species of the group is provided.
\end{abstract}

RESUMEN: En Epidendrum, siendo considerado un género monofilético, se pueden reconocer diversos grupos de especies con características vegetativas y florales similares. La revisión de uno de estos grupos, el grupo $E$. macrostachyum, el cual se reconoce por su hábito monopodial con ramificaciones subapicales, inflorescencia apical, erecta y flores no resupinadas, carnosas con el labelo entero abrazando la columna y pubescente por lo menos en la base, ha permitido la descripción de varias especies nuevas, entre ellas la nueva especie que se describe y se ilustra aquí. Es una especie colombiana similar a Epidendrum microrigidiflorum, sin embargo difiere por la inflorescencia (dística, 6 flores vs. racemosa, 8-16 flores), en la forma (trulado vs. anchamente rómbico) y ornamentación del labelo (densamente seríceo vs. diminutamente papiloso) y en la ausencia de callos en el disco del mismo (ecalloso vs. bicalloso). Se presenta además una clave de las 41 especies del grupo.

KeY words: Colombia, Orchidaceae, Epidendrum, new species, Epidendrum macrostachyum group

Introduction. The genus Epidendrum L. was described by Linnaeus in 1763. It originally included most of the tropical epiphytic orchids, presently placed in other genera of the Orchidaceae family such as Arachnis Blume, Brassavola R.Br., Brassia R.Br., Prosthechea Knowles \& Westc., among others. The genus was conserved by the Botanical Congress of 1930 with Epidendrum nocturnum Jacq. chosen as the conserved type (Sprague 1929). In 2005 Hágsater and Soto calculated that Epidendrum included over 1500 species, distributed from southern United States to northern Argentina. Today we believe that the number is closer to 2400 , of which over 1100 having been recently illustrated and described mostly in the series Icones Orchidacearum (Hágsater \& Salazar 1993; Hágsater et. al. 1999; Hágsater \& Sánchez 2001, 2004, 2006, 2007, 2008, 2009, 2010, 2013, 2015). It is considered one of the largest genera of Neotropical orchids, and includes terrestrial, epiphytic or lithophytic plants that grow in different types of vegetation ranging from tropical forest, dunes and scrubs to Andean páramos (Hágsater \& Soto 2005; Chase et al. 2015). The classification of Epidendrum has been a difficult task for numerous authors due to the great variation of floral and vegetative characteristics, as well as the similarity of herbarium specimens. There 
have been various attempts throughout the years to separate numerous species included in the genus. Thus various authors have proposed some natural groups in Epidendrum as separate genera, as it the case of Epidanthus L.O.Williams (Williams 1940), or more recently Takulumena Szlach. (Szlachetko et al. 2006; Szlachetko et al. 2014), based on characteristics that seem simple, but which appear repeatedly in various groups of otherwise not closely related species, such as the number of pollinia, or the position of the inflorescence on the stem. With some 300 species sequenced in its DNA, the genus is monophyletic though diverse groups and sub-groups can be recognized (Hágsater \& Soto 2005). Among these groups, the E. macrostachyum group with more than 41 recognized species is a difficult one because, the plants and flowers are all very similar at first sight, though careful study of vegetative and floral characteristics, as well as their distributional range, facilitates their identification, some species are sympatric.

They are distributed from Costa Rica to Bolivia and from 670 to $3600 \mathrm{~m}$ elevation. It is characterized by having monopodial plants with sub-apical branching from a primary stem, the inflorescence is erect and generally racemose (occasionally distichous), with variously colored, fleshy flowers, of different sizes, and the lip entire and generally more or less pubescent, at least near the base. Due to the lack of understanding of the group, authors such as Dunsterville and Garay (1972) reduced many species (E. bangii Rolfe, E. chondrochilum F.Lehm. \& Kraenzl., E. coordinatum Rchb.f., E. dermatanthum Kraenzl., E. magnibracteum Kraenzl. E. rigidiflorum Schltr., E. rostrigerum Rchb.f., E. xylostachyum Lind1.) from Costa Rica, Colombia, Ecuador, Peru and Bolivia to synonyms of Epidendrum macrostachyum Lindl. (non Epidendrum macrostachya Thouars = Beclardia macrostachya (Thouars) A. Rich).

Detailed revision of numerous herbarium specimens, and photographs of live material, as well as personal field experience of the first author has led us to propose that all these the above mentioned names correspond to discrete entities (Santiago \& Hágsater 2013, 2015a, b, c, d, e). In addition, a number of new species from Venezuela, Colombia, Ecuador and Peru have been recently added to the E. macrostachyum group: E. borealistachyum
Hágsater, E.Santiago \& C.Fernández (Hágsater et al. 2015) E. brachyoothistachyum Hágsater \& E.Santiago (Hágsater \& Santiago 2015a), E. brachystelestachyum Hágsater, E.Santiago \& ReinaRodr., (Hágsater et al. 2015), E. cardiostachyum Hágsater \& E. Santiago (Hágsater \& Santiago 2015b), E. deltastachyum Hágsater \& E.Santiago (Hágsater \& Santiago 2015c), E. erikae Hágsater \& E.Santiago (Hágsater \& Santiago 2015d), E. macphersonii Hágsater \& E.Santiago (Hágsater \& Santiago 2015e), E. munchiquense Hágsater, E. Santiago \& GarcíaRevelo, (Hágsater et al. 2015), E. notostachyum Hágsater \& E.Santiago (Hágsater \& Santiago 2015f), E. odontostachyum Hágsater \& E.Santiago (Hágsater \& Santiago, 2015j), E. porphyrostachyum Hágsater \& E.Santiago (Hágsater \& Santiago 2015k), E. puracestachyum Hágsater \& E.Santiago (Hágsater \& Santiago 20151), E. recurvitepalostachyum Hágsater \& E.Santiago (Hágsater \& Santiago 2015m), E.sarcostachyum Hágsater, E.Santiago \& E. Becerra, (Hágsater et al. 2015), E.sigmostachyum Hágsater, E.Santiago \& D.Trujillo (Hágsater et al. 2015), E. stenobractistachyum Hágsater \& E.Santiago (Hágsater \& Santiago 2015n), and E. sumacostachyum Hágsater \& E.Santiago (Hágsater \& Santiago 2015o). The species described below is another example of such new entities.

Material and methods. A revision of nearly 700 herbarium specimens from numerous different collectors, years and countries including Venezuela, Costa Rica, Colombia, Ecuador, Peru and Bolivia was done. The specimens mostly shelved under Epidendrum macrostachyum are deposited in herbaria including AAU, AMO, AMES, C, CAUP, COL, CUVC, CUZ, F, G, GB, HPUJ, HUA, JAUM, K, L, LE, LOJA, MO, MOL, QCA, QCNE, RENZ, S, SEL, U, US, USJ, USM, VALLE, VEN, NY and W. For specimens on loan floral segments were drawn using a camera lucida mounted on a dissecting microscope. For selected specimens complete illustrations including vegetative and reproductive traits (e.g. floral segments, lip and nectary ornamentation) were prepared. Numerous photographs taken in the field and provided by numerous photographers and on internet were registered and analyzed. Eric Hágsater has travelled extensively in Ecuador, Colombia and 


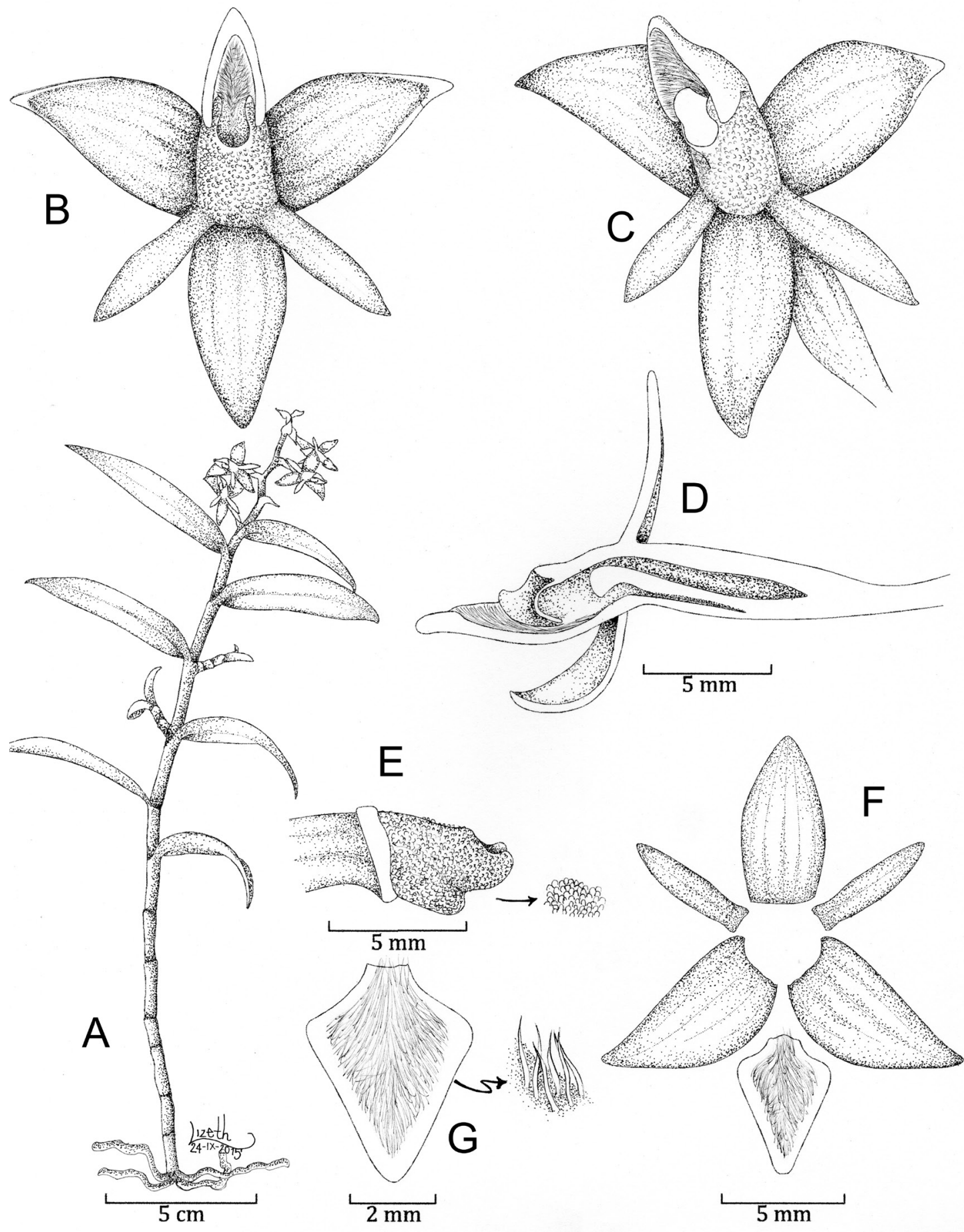

Figure 1. Epidendrum lasiostachyum. A. Habit. B. Flower, frontal view. C. Flower, lateral view. D. Flower, longitudinal section. E. Column details. F. Dissected perianth. G. Lip details. Drawn by Lizeth Rodríguez M. from the holotype $(L$. Rodríguez-Martínez 254). 


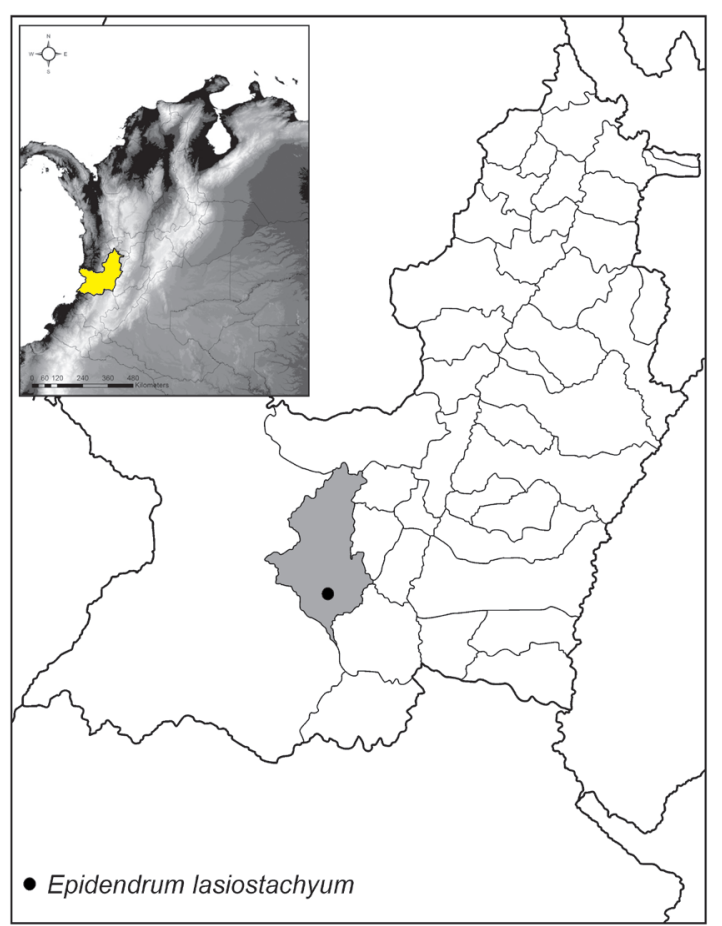

FIGURE 2. Distribution map of the species Epidendrum lasiostachyum in Colombia.

Peru between 1970 and 2016, collecting and studying the genus Epidendrum, photographing and collecting numerous specimens.

Lizeth Rodríguez Martínez, a student of agronomy at the Universidad Nacional de Colombia, campus Palmira, made several field trips during 2014 in the Department of Valle del Cauca, Colombia, discovering the population of the species here proposed and described. Individual plants were photographed, flowers were preserved in alcohol, and an illustration prepared (Fig. 1), prior to pressing and desiccation of one specimen and deposited at COL (holotype). Phenology data were recorded in the field. Morphological studies were carried out using a Zeiss stemi 2000 stereomicroscope. A distribution map was produced using ArcMAP (Fig. 2).

\section{TAXONOMIC TREATMENT}

Epidendrum lasiostachyum Rodr--Martínez, Hágsater \& E.Santiago, sp. nov. (Fig. 3).

TYPE: Colombia. Valle del Cauca: Municipio Dagua, Corregimiento San José del Salado, relicto de bosque muy húmedo, epífita de árbol de Tibouchina sp., 1800-1900 m, 21 November 2014, Lizeth RodríguezMartínez 254 (holotype: COL!).

Diagnosis: The species is similar to Epidendrum microrigidifloum Hágsater (Hágsater 2006), but the plants are smaller, $25-30 \mathrm{~cm}$ tall (vs. $60-100 \mathrm{~cm}$ tall) with a distichous, 6-flowered inflorescence (vs. racemose and 8-16-flowered); petals small, 4-5 mm long (vs. $6.8 \mathrm{~mm}$ long), and the lip is trullate, densely sericeous (vs. scarcely papillose), and ecallose (vs. bicallose).

Epiphytic, monopodial, caespitose, erect herb, 25-30 cm tall. Roots $1.5-2.0 \mathrm{~mm}$ in diameter, filiform. Stems $20-25 \times 0.3-0.5 \mathrm{~cm}$, cane-like, terete, erect, branching when mature, base covered by sheaths 1.2 $1.6 \mathrm{~cm}$ long, tubular, non-foliar, scarious. Leaves 7 , distributed throughout the stems, articulate to the foliar sheath, spreading with respect to the stem, similar in size and shape, green, concolor; sheaths $1.5-2.5 \mathrm{~cm}$ long, tubular, minutely striated, rugose, pale green; blade $4.5-6.0 \times 0.8-1.0 \mathrm{~cm}$, lanceolate, apex acute, margin minutely serrate. Inflorescence $6 \mathrm{~cm}$ long, apical, developing from mature stems, distichous, erect, laxly few-flowered; peduncle 5-7 $\times 1.5-2.0$ $\mathrm{mm}$, terete, thin, straight; rachis $5.0-5.5 \times 0.1-0.2 \mathrm{~cm}$, slightly flexuous, greenish. Floral bracts 5-7 $\times 2 \mathrm{~mm}$, much shorter than the ovary, triangular-lanceolate, apex acute, margin slightly serrate, embracing, perpendicular to the rachis. Flowers 6 , simultaneous, non resupinate, distichous, secund, distributed along the rachis; sepals and petals yellow, lip pale yellow, column greenish yellow with the apex purple; without fragrance. Ovary $15 \times 2 \mathrm{~mm}$, terete, thin, striated, lime green. Sepals 7-8 × 3-4 mm, free, spreading, fleshy, narrowly ovate, apex acute, 5 -veined, margin entire, spreading; lateral sepals oblique, slightly falcate. Petals 4-5 $\times 1.5 \mathrm{~mm}$, spreading, free, oblong-oblanceolate, apex acute, 1-veined, margin entire, spreading. Lip 7 $\times 4 \mathrm{~mm}$, united to the column, entire, trullate, the base widely cuneate, apex narrowly rounded, embracing the column in natural position without covering it; ecallose, densely sericeous, the trichomes covering the entire surface of the lip except for the margin, and reclining towards the nectary. Column 4-5 mm long, short, thick, slightly arched at the base, apex deflexed, the surface minutely papillose. Clinandrium reduced, 

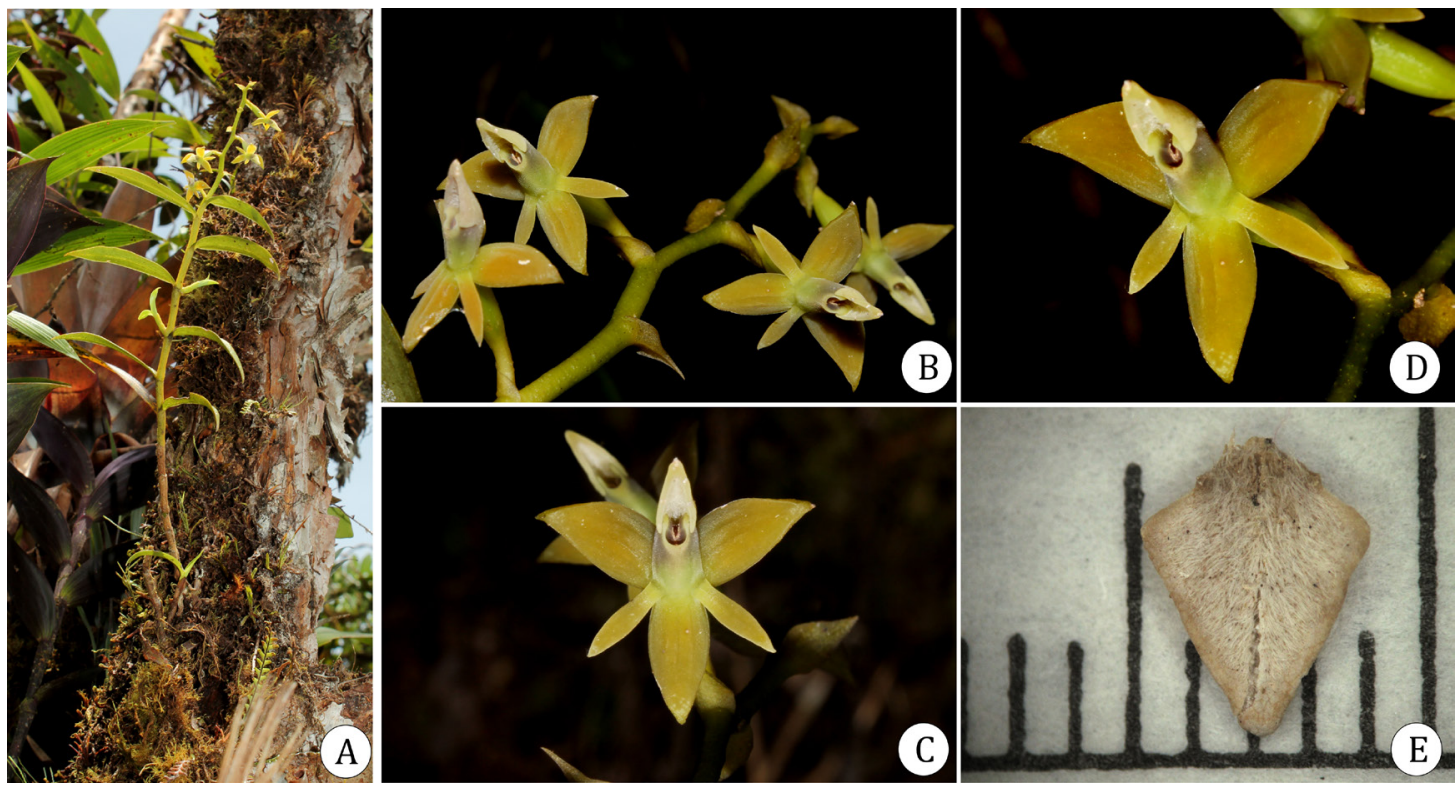

FiguRE 3. Epidendrum lasiostachyum photographed in situ by L. Rodríguez Martínez (based on the pretype: L. Rodríguez

Martínez 254). A. Habit and complete plant. B. Inflorescence details. C \& D show different angles of the flower. E. Lip details.

margin entire. Anther not seen. Rostellum apical, slit. Nectary penetrating 2/3 of the ovary, densely sericeous in front of the stigmatic cavity. Capsule not seen.

Distribution AND ECOlOgY: It is known presently from the western slope of the Western Cordillera of the Andes, only from one collection from the mountains of San José del Salado, Municipality of Dagua in the Department of Valle del Cauca, Colombia, at an elevation of $1850 \mathrm{~m}$. It is found as an epiphyte in the cloud forests on the western mountain range. Two specimens were found growing on Tibouchina sp. (Melastomataceae). Flowering in November. Growing fully exposed to the sun, along the edge of the forest and pastures, as part of secondary vegetation. Annual mean precipitation is $2000 \mathrm{~mm}$, with constant fog in the early morning and late afternoon. Mean temperature is $17^{\circ} \mathrm{C}$, slopes are steep (50-75\%). Nearby forests are $25 \mathrm{~m}$ tall. The best represented genera were Palicourea Aubl., Psychotria L., Miconia Ruiz \& Pav., Solanum L., Cavendishia Lindl. and Clusia L. and the dominant species: Otoba lehmannii (A.C. Sm.) A.H. Gentry, Ladenbergia oblongifolia (Humb, ex Mutis) L. Andersson, Myrsine coriacea (Sw.) R. Br., Saurauia scabra (Kunth) D.Dietr., Alchornea latifolia Sw.,
Ficus tonduzii Standl., Ficus andicola Standl., Meriania nobilis Triana, Clausia sp., Miconia sp. and Schefflera sp. (Hágsater et al., 2015).

EтумоLоGy: From the Greek $\lambda \alpha \sigma i o s$, shaggy, woolly, and $\sigma \tau \alpha \chi \cup \varsigma$, ear of corn; in reference to the lip which is completely (but not the margin) covered by long, straight trichomes reclining towards the nectary that distinguishes this species from others members of the E. macrostachyum group.

Discussion. The species is similar to Epidendrum microrigidiflorum Hágsater but differs mainly in the size of the plant (25-30 cm tall) (Fig. 3A), the fewflowered inflorescence, distichous, with the rachis slightly flexuous (Fig. 3B), the flowers somewhat smaller (Fig. 3C, 3D), and the trullate lip with the base widely cuneate and the apex obtuse, sericeous (Fig. 3E) and the column minutely papillose (Fig. 1E). Epidendrum microrigidiflorum has larger plants $(60-100 \mathrm{~cm}$ tall), the inflorescence secund and many-flowered and the lip is widely rhombic with the apex apiculate, surface scarcely papillose on the disc and the column unornamented (Fig. 4). Epidendrum notostachyum Hágsater \& E.Santiago (Fig. 5) differs in the color and size of the flowers, 


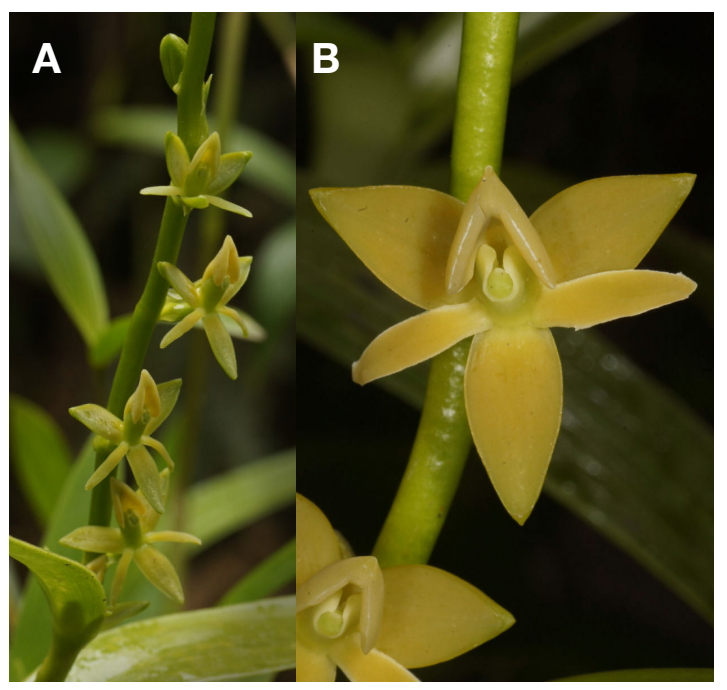

FIGURE 4. Inflorescence (A) and flower (B) of Epidendrum microrigidiflorum, photographed by Gary Yong. Panamá, Reserva de la biosfera La Amistad.

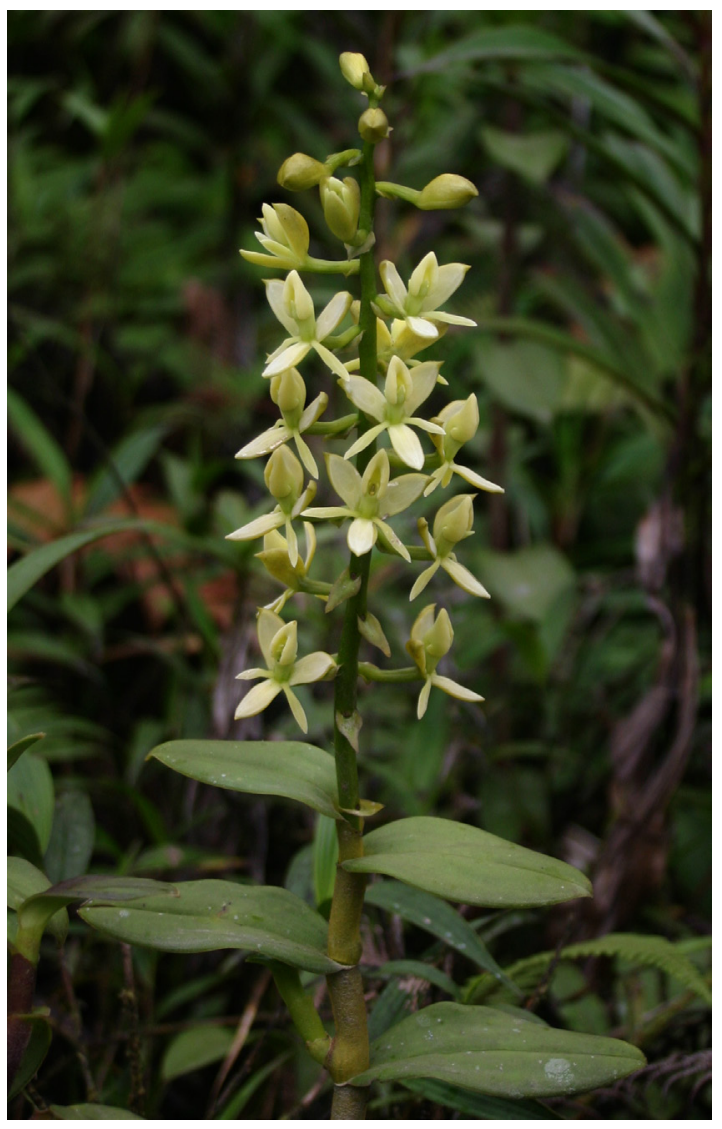

FIGURE 5. Inflorescence of Epidendrum notostachyum, photographed by Hugo Medina. Ecuador.

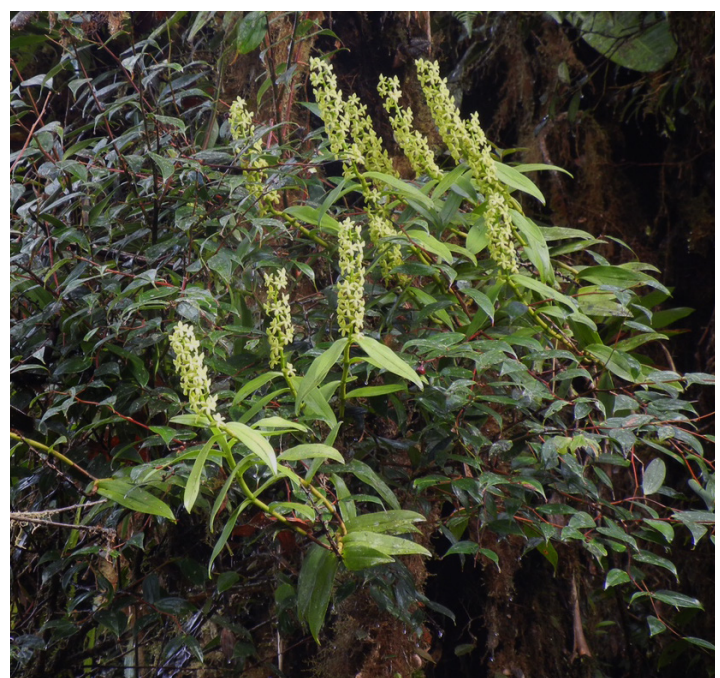

FIGURE 6. Plant and inflorescence of Epidendrum polyanthostachyum, photographed by Patricia Harding, Colombia, Chocó.

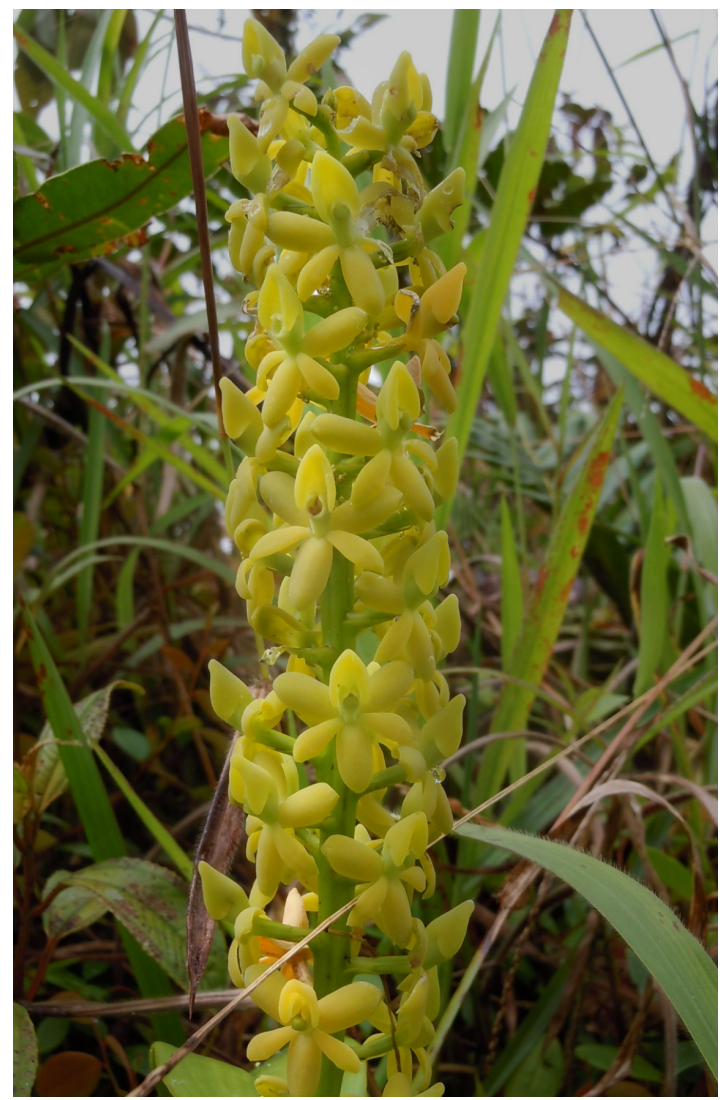

FIGURE 7. Inflorescence of Epidendrum polyanthostachyum, photographed by Duván Andrés García Ramírez, Colombia, Valle del Cauca. 


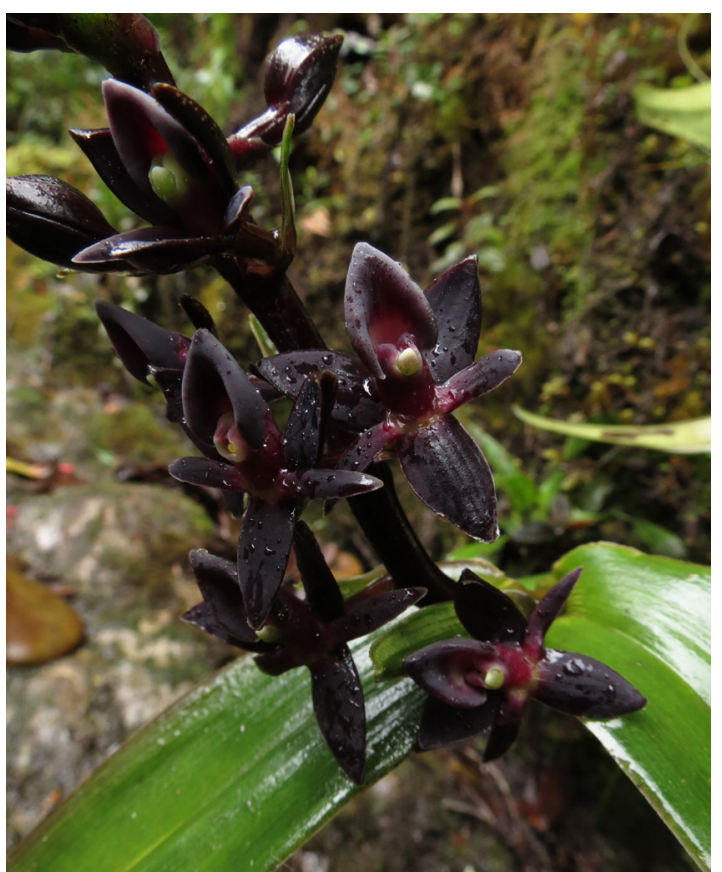

FIGURE 8. Inflorescence of Epidendrum macrostachyum, photographed by David Haelterman, Colombia, Cauca. sepals are 9.0-9.5 $\mathrm{mm}$ long, dorsally papillose and the lip scarcely pubescent at the base with the base truncate. Epidendrum polyanthostachyum Hágsater, E.Santiago \& García-Ramírez has a densely cylindrical, many-flowered inflorescence (Fig. 6 and 7), the leaves lanceolate, (3.5-14 × 1.8-4.7 $\mathrm{cm}$ ), the lip scarcely pubescent at the base, widely deltoid with the base cordate. Finally, Epidenrum macrostachyum Lindl. has large, triangular ovate floral bracts ( $8-18 \mathrm{~mm}$ long), with flowers the color of ripe olives or lack-brown and the leaves elliptic $(12.5-13 \times 3.0-3.5 \mathrm{~cm})($ Fig. 8$)$.

ACKNOWLEDGEMENTS. We wish to thank the participation of Dr. Guillermo Reina-Rodríguez, researcher at the Universidad del Valle, Cali, Colombia, for his valuable information provided on the Corregimiento San José del Salado, Dagua Municipality. We also wish to acknowledge Gary Young (Australia), Hugo Medina (Ecuador), Duván Andrés García Ramírez (Colombia) and David Haelterman (Belgium) as well as Patricia Harding (United States of America) for supplying and permitting us the use of the digital images that complement this paper.

KEY TO THE SPECIES OF THE MACROSTACHYUM GROUP

1. Floral bracts prominent (never shorter that the ovary to much longer that the flower) $11-40 \mathrm{~mm}$ long [the apical ones may diminish to 5-7 $\mathrm{mm}$ long]

1'. Floral bracts small (shorter that the ovary to rarely somewhat longer) 2.5-9[12] mm long …............................... 2

2(1'). Inflorescence densely flowered (35-70 flowers)

2'. Inflorescence laxly flowered (8-30 flowers)

3(2). Flowers small, sepals 5-8 mm long, dorsally muricate

3'. Flowers larger, sepals 11-15 mm long, dorsally unornamented

E palacio

$4\left(2^{\prime}\right)$. Flowers green, yellow or orange, inflorescence lax-flowered

4'. Flowers lilaceous white, rarely deep lilac, inflorescence dense

E. polyanthostachyum

5(4). Leaves elliptic or narrowly elliptic, $8-18 \times[2.2] 3-5 \mathrm{~cm}$ on the main stem; lip clearly cordiform; sepals 14-18 mm long

E. cardiostachyum

5'. Leaves lanceolate to linear lanceolate, 6-15 $\times 0.6-1.7$ [2.3] $\mathrm{cm}$ on the main stem; lip deltoid, sub-deltoid to widely rhombic; sepals $6.5-13 \mathrm{~mm}$ long

6(5'). Inflorescence $20 \mathrm{~cm}$ long; sepals 12-13 mm long; lip sub-deltoid with the base cordate E..... E. odontostachyum

6'. Inflorescence 5-13 [15] cm long; sepals 6-12 mm long; lip deltoid or widely rhombic, base truncate, slightly sub-cordate or cuneate

7(6'). Lip densely pubescent throughout its ventral surface

\section{7}

$8\left(7^{\prime}\right)$. Sepals $6-7.5 \mathrm{~mm}$ long 8

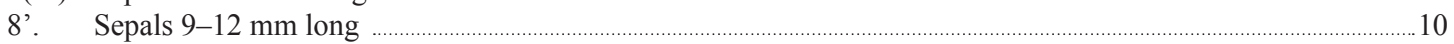

9(8). Inflorescence $5 \mathrm{~cm}$ long; flowers 8-12; petals $5 \times 1 \mathrm{~mm}$, linear, the apex obtuse; column $3 \mathrm{~mm}$ long

E. microcarpum

9'. Inflorescence 7-8 cm long; flowers $15-17$; petals $6.7 \times 1.5 \mathrm{~mm}$, oblong, falcate, the apex acute; column $7 \mathrm{~mm}$

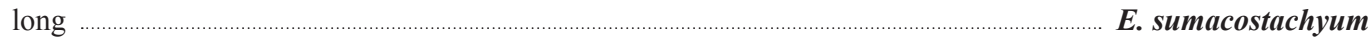

10(8') Sepals 9.0-9.5 mm long, dorsally papillose; petals $8 \times 1.5 \mathrm{~mm}$; linear-oblanceolate; ovary $5-7 \mathrm{~mm}$ long

10'. Sepals 9-12 mm long, dorsally glabrous; petals $10 \times 1.3 \mathrm{~mm}$, linear; ovary 7-10 mm long E. grammipetalostachym 


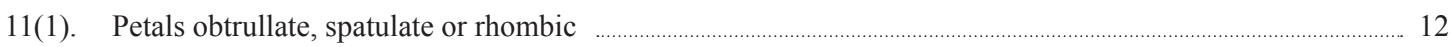

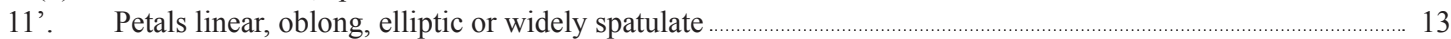

12(11). Leaves of the main stem $8.5-9.0 \times 1.5-1.7 \mathrm{~cm}$; lip $7 \times 9 \mathrm{~mm}$, trullate with the apex rounded, ecallose

E. trullichilum

12'. Leaves of the main stem 9-17 $\times 2.8-4.5 \mathrm{~cm}$; lip $9 \times 12 \mathrm{~mm}$, widely triangular cordiform with the apex subacute, bicallose

E. orthophyllum

13(11'). Inflorescence short (1.5-3.0 cm long), with 3-4 flowers densely aggregate in a very short rachis; leaves linearlanceolate

E. platystachyum

13'. Inflorescence long (7-34 cm long), with 5-21 flowers distributed along the rachis; leaves lanceolate, elliptic to oblong-elliptic

$14\left(13^{\prime}\right)$. Floral bracts proportionately nearly as wide as they are long, the apex acute or short-acuminate ..................... 15

14'. Floral bracts proportionately longer than wide, the apex acute or long-acuminate ………........................ 23

15(14). Leaves narrowly elliptic-lanceolate, elliptic or oblong-lanceolate, $1.4-5 \mathrm{~cm}$ wide; lip $10-17 \times 11-18 \mathrm{~mm} \ldots \ldots \ldots . . .16$

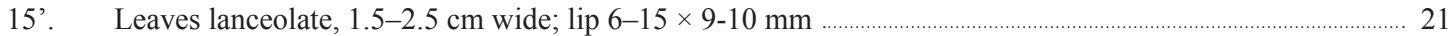

16(15). Mature inflorescence much longer than the apical leaf, many-flowered, with 18-20 flowers ........................... 17

16'. Mature inflorescence as long or slightly shorter than the apical leaf, few-flowered, with 5-8 flowers ........... 20

17(16). Petals oblanceolate, widely spatulate or obovate-elliptic, flowers colorful, never green; anther with the apex obtuse; ovary 9-19 mm long

17'. Petals oblong, flowers green, the lip greenish yellow; anther apically short acuminate; ovary very short $6 \mathrm{~mm}$ long.

E. brachyoothistachyum

18(17). Flowers white tinged with purple; petals $15 \times 5 \mathrm{~mm}$, oblanceolate

E. obovatipetalum

18'. Flowers reddish orange to lilac; petals $13.2-14.0 \times 6-8 \mathrm{~mm}$, widely spatulate to obovate-elliptic

19(18). Flowers 15-20, lilac; petals obliquely obovate-elliptic with the apex sub-obtuse; lip ecallose ............. E. erikae

19'. Flowers ca. 45, reddish-orange; petals widely spatulate and the apex rounded; lip bicallose _........... E. ariasii

$20\left(16^{\prime}\right)$. Inflorescence $6.5 \mathrm{~cm}$ long; sepals $15 \times 9 \mathrm{~mm}$; petals nearly as wide as the sepals; flowers greenish white

E. xylostachyum

20'. Inflorescence $8-13 \mathrm{~cm}$ long; sepals $21 \times 12.5 \mathrm{~mm}$; petals half as wide as the sepals; flowers yellowish green

E. humeadorense

$21\left(15^{\prime}\right)$. Lateral sepals partly spreading, slightly concave; petals linear-oblanceolate to lanceolate, spreading _.......... 22

21'. Lateral sepals reflexed, convex; petals oblanceolate, reflexed …………………. E. recurvitepalostachyum

22(21). Rachis of the inflorescence straight; floral bracts 5-7 mm wide, the apex acute; lateral sepals very fleshy; petals linear-oblanceolate

E. sarcostachyum

22'. Rachis of the inflorescence sinuous; floral bracts $8-12 \mathrm{~mm}$ wide, the apex acuminate and uncinate; lateral sepals slightly fleshy; petals lanceolate

E. chondrochilum

23(14'). Floral bracts much longer than the total length of the flower

24

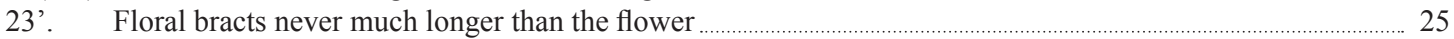

24(23). Leaf blade of the main stem 18-20 × 2-5 cm, elliptic-lanceolate; inflorescence pyramidal, the rachis straight; flowers successive 21-30; ovary 6-7 mm long; lip widely cordiform (proportionately wider than long); sepals ovate-elliptic, obtuse

E. magnibracteum

24'. Leaf blade of the main stem 15-18 x 2-2.8 cm, narrowly lanceolate; inflorescence distichous with the rachis fractiflex; flowers mostly simultaneous, 11-12; ovary 9-12 mm long; lip cordiform (as wide as it is long); sepals triangular-ovate, acute

E. bractiacuminatum

25(23'). Inflorescence of the main stem 2.5-9.0 [13-17] cm long ……........................................................... 26

25'. Inflorescence of the main stem 15-40 cm long .

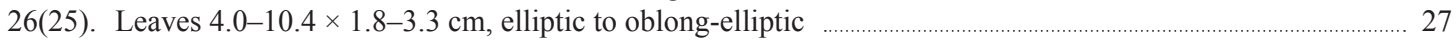

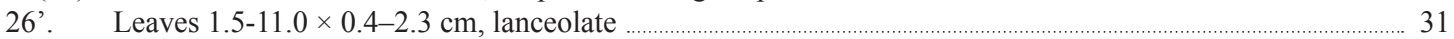

27(26). Anther with the apex acute or truncate, never surpassing the apex of the column; sepals $13.5-17 \times 4-7 \mathrm{~mm} \quad \ldots . .28$

27'. Anther with the apex rostrate, surpassing the apex of the column; sepals 9-12 $\times 3-5 \mathrm{~mm} \ldots \ldots \ldots \ldots \ldots \ldots \ldots \ldots \ldots \ldots . . . .29$

28(27). Flowers peach colored; petals linear-oblong; sepals dorsally glabrous; column sigmoid ......... E. sigmostachyum

28'. Flowers green tinged brown, turning orange-brown when mature; petals oblong-elliptic; sepals dorsally echinate; column straight

E. deltastachyum

29(27'). Lateral sepals with a high, laminar, dorsal keel, the apex erose; petals oblong, apex rounded; anther with a short, incipient apical rostrum shorter than the anther itself; flowers red

E. macphersonii

29'. Lateral sepals with a low, incipient dorsal keel, the margin entire; petals linear, apex acute; anther with an apical rostrum much longer than the body of the anther; flowers green 
30(29'). Inflorescence $13 \mathrm{~cm}$ long; sepals 9-11 mm long, apex acute; lip 6.5-8.0 × 7-10 mm, semi-circular with the base sub-truncate, without ribs; column 5-6 $\mathrm{mm}$ long

E. rostrigerum

30'. Inflorescence 5-8 cm long; sepals 10-13 mm long, apex acute; lip 9-10 $\times 9-11 \mathrm{~mm}$, deltoid with the base truncate, with a low rib down the middle; column 7-8 mm long

E. probosantherum

31(26'). Flowers small, sepals 7.5-7.8 mm long; inflorescence secund flowered; lip rhombic, the base cuneate

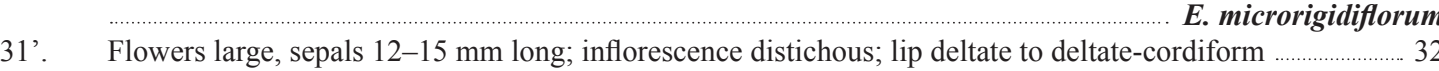

32(31'). Sepals 14-15 mm long, slightly recurved, the apex minutely apiculate; floral bracts narrowly oblong or triangular-lanceolate

E. stenobractistachyum

32'. Sepals $12.0-13.7 \mathrm{~mm}$ long, partly spreading to spreading, the apex uncinate; floral bracts ovate-lanceolate

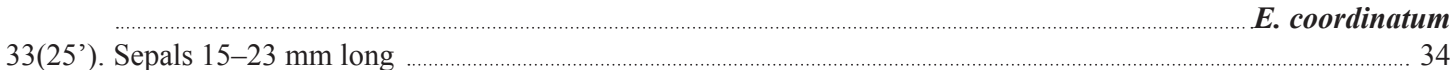

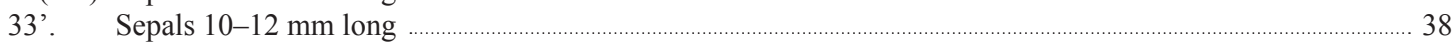

34(33). Rachis of the inflorescence slightly flexuous; flowers 6-15; lip $14.5 \times 14.4 \mathrm{~mm} \ldots \ldots \ldots \ldots \ldots \ldots \ldots \ldots \ldots \ldots \ldots \ldots \ldots . . . . \quad$ E. bangii

34'. Rachis of the inflorescence straight; flowers 15-27; lip 9-12 × 8-12 mm …................................................ 35

35(34'). Sepals and petals long acuminate; sepals $15-23 \mathrm{~mm}$ long ........................................................

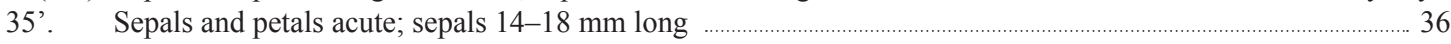

$36\left(35^{\prime}\right)$. Inflorescence (of the main stem) 24-40 cm long; flowers wine-red ……………............................................ 37

36'. Inflorescence (of the main stem) 11-14 cm long; flowers reddish brown ................................. E. dermatanthum

37(36). Inflorescence lax flowered, $25-40 \mathrm{~cm}$ long; leaves green with the margin reddish; column wide and straight

E. munchiquense

37’. Inflorescence densely flowered, $24 \mathrm{~cm}$ long; leaves wine-red; column thin and slightly arched

E. porphyrostachyum

$38\left(33^{\prime}\right)$. Leaves narrowly lanceolate, apex acute to short acuminate, leaves of the main stem 1.6-2.5 cm wide; inflorescence $15-23 \mathrm{~cm}$ long, flowers yellow to greenish yellow or wine-red

38'. Leaves lanceolate elliptic, apex acute; leaves of the main stem 3.0-3.5 cm wide; inflorescence to $31 \mathrm{~cm}$ long, flowers the color of ripe black olives

39(38). Flowers wine-red; leaves $5.3-8.0 \mathrm{~cm}$ long, lanceolate, apex acute; petals oblong-triangular, never falcate

E. puracestachyum

39'. Flowers yellow to greenish yellow; leaves $7.5-18.0 \mathrm{~cm}$ long, lanceolate, apex acuminate; petals linear and falcate

E. rigidiflorum

40(38'). Petals linear-oblong, apex sub-obtuse; lip widely cordiform, base slightly cordate, column thin

$40^{\prime}$

Petals linear-triangular, apex sub-acute; lip triangular, base truncate; column thick

E. macrostachyum

E. brachystelestachyum

\section{LITERATURE CITED}

Chase, M.W., Cameron, K.M., Freudenstein, J.V., Pridgeon, A.M., Salazar, G., van den Berg, C. \& Schuiteman, A. (2015). An updated classification of Orchidaceae. Botanical Jounal of the Linnean Society, 177,151-174.

Dunsterville, G.C.K. \& Garay, L.A. (1972). Venezuelan Orchids Illustrated V. London: Andre Deutsch.

Hágsater, E. (2006). Epidendrum microrigidiflorum. In E. Hágsater \& L. Sánchez S. (eds.), The Genus Epidendrum, Part 5, Icones Orchidacearum 8 (t) 853). México: Instituto Chinoin, A. C.

Hágsater, E. \& Santiago, E. (2015a). Epidendrum brachyoothistachyum. In E. Hágsater \& L. Sánchez S. (eds.), The Genus Epidendrum, Part 11, Icones
Orchidacearum 15(1) (t. 1507). México: Instituto Chinoin, A. C.

Hágsater, E. \& Santiago, E. (2015b). Epidendrum cardiostachyum. In E. Hágsater \& L. Sánchez S. (eds.), The Genus Epidendrum, Part 11, Icones Orchidacearum 15(1) (t. 1510). México: Instituto Chinoin, A. C.

Hágsater, E. \& Santiago, E. (2015c). Epidendrum deltastachyum. In E. Hágsater \& L. Sánchez S. (eds.), The Genus Epidendrum, Part 11, Icones Orchidacearum 15(1) (t. 1518). México: Instituto Chinoin, A. C.

Hágsater, E. \& Santiago, E. (2015d). Epidendrum erikae. In E. Hágsater \& L. Sánchez S. (eds.), 
The Genus Epidendrum, Part 11, Icones Orchidacearum 15(1) (t. 1521). México: Instituto Chinoin, A. C.

Hágsater, E. \& Santiago, E. (2015e). Epidendrum macphersonii. In E. Hágsater \& L. Sánchez S. (eds.), The Genus Epidendrum, Part 11, Icones Orchidacearum 15(1) (t. 1536). México: Instituto Chinoin, A. C.

Hágsater, E. \& Santiago, E. (2015f). Epidendrum notostachyum. In E. Hágsater \& L. Sánchez S. (eds.), The Genus Epidendrum, Part 11, Icones Orchidacearum 15(1) (t. 1545). México: Instituto Chinoin, A. C.

Hágsater, E. \& Santiago, E. (2015j). Epidendrum odontostachyum. In E. Hágsater \& L. Sánchez S. (eds.), The Genus Epidendrum, Part 11, Icones Orchidacearum 15(1) (t. 1547). México: Instituto Chinoin, A. C.

Hágsater, E. \& Santiago, E. (2015k). Epidendrum porphyrostachyum. In E. Hágsater \& L. Sánchez S. (eds.), The Genus Epidendrum, Part 11, Icones Orchidacearum 15(1) (t. 1550). México: Instituto Chinoin, A. C.

Hágsater, E. \& Santiago, E. (20151). Epidendrum puracestachyum. In E. Hágsater \& L. Sánchez S. (eds.), The Genus Epidendrum, Part 11, Icones Orchidacearum 15(1) (t. 1552). México: Instituto Chinoin, A. C.

Hágsater, E. \& Santiago, E. (2015m). Epidendrum recurvitepalostachyum. In E. Hágsater \& L. Sánchez S. (eds.), The Genus Epidendrum, Part 11, Icones Orchidacearum 15(1) (t. 1554). México: Instituto Chinoin, A. C.

Hágsater, E. \& Santiago, E. (2015n). Epidendrum stenobractistachyum. In E. Hágsater \& L. Sánchez S. (eds.), The Genus Epidendrum, Part 11, Icones Orchidacearum 15(1) (t. 1562). México: Instituto Chinoin, A. C.

Hágsater, E. \& Santiago, E. (2015o). Epidendrum sumacostachyum. In E. Hágsater \& L. Sánchez S. (eds.), The Genus Epidendrum, Part 11, Icones Orchidacearum 15(1) (t. 1563). México: Instituto Chinoin, A. C.

Hágsater E., Santiago, E. \& Fernandez, C. (2015). Epidendrum borealistachyum. In E. Hágsater \& L. Sánchez S. (eds.), The Genus Epidendrum, Part 11, Icones Orchidacearum 15(1) (t. 1505). México:
Instituto Chinoin, A. C.

Hágsater E., Santiago, E. \& Becerra, E. (2015). Epidendrum sarcostachyum. In E. Hágsater \& L. Sánchez S. (eds.), The Genus Epidendrum, Part 11, Icones Orchidacearum 15(1) (t. 1558). México: Instituto Chinoin, A. C.

Hágsater E., Santiago, E. \& Trujillo, D. (2015). Epidendrum sigmostachyum. In E. Hágsater \& L. Sánchez S. (eds.), The Genus Epidendrum, Part 11, Icones Orchidacearum 15(1) (t. 1560). México: Instituto Chinoin, A. C.

Hágsater E., Santiago, E. \& Reina-Rodríguez, G.. (2015). Epidendrum brachystelestachyum. In E. Hágsater \& L. Sánchez S. (eds.) The Genus Epidendrum, Part 11, Icones Orchidacearum 15(1) (t. 1509). México: Instituto Chinoin, A. C.

Hágsater E., Santiago, E. \& García-Revelo, S. (2015). Epidendrum munchiquense. In E. Hágsater \& L. Sánchez S. (eds.) The Genus Epidendrum, Part 11, Icones Orchidacearum 15(1) (t. 1544). México: Instituto Chinoin, A. C.

Hágsater, E., \& Salazar, G.A. (eds.). (1993). The genus Epidendrum, part 1, A century of new species in Epidendrum, Icones Orchidacearum 2 (t. 101200). México: Instituto Chinoin, A. C.

Hágsater E., Reina-Rodríguez, G. \& Rodríguez M., L. (2015). Epidendrum chilcalorum. In E. Hágsater \& L. Sánchez S. (eds.) The Genus Epidendrum, Part 11, Icones Orchidacearum 15(1) (t. 1512). México: Instituto Chinoin, A. C.

Hágsater, E., Sánchez Saldaña, L \& García-Cruz, J. (eds.). (1999). The genus Epidendrum, part 2, A second century of new species in Epidendrum, Icones Orchidacearum 3 (t. 301-400). México: Instituto Chinoin, A. C.

Hágsater, E., \& Sánchez Saldaña, L (eds.). (2001). The genus Epidendrum, part 3, A third century of new species in Epidendrum, Icones Orchidacearum 4 (t. 401-500). México: Instituto Chinoin, A. C.

Hágsater, E., \& Sánchez Saldaña, L (eds.). (2004). The genus Epidendrum, part 4, A fourth century of new species in Epidendrum, Icones Orchidacearum 7 (t. 701-800). México: Instituto Chinoin, A. C.

Hágsater, E., \& Sánchez Saldaña, L (eds.). (2006). The genus Epidendrum, part 5, Species new \& old in Epidendrum, Icones Orchidacearum 8 (t. 801900). México: Instituto Chinoin, A. C. 
Hágsater, E., \& Sánchez Saldaña, L (eds.). (2007). The genus Epidendrum, part 6, Species new \& old in Epidendrum, Icones Orchidacearum 9 (t. 9011000). México: Instituto Chinoin, A. C.

Hágsater, E., \& Sánchez Saldaña, L (eds.). (2008). The genus Epidendrum, part 7, Species new \& old in Epidendrum, Icones Orchidacearum 11 (t. 11011200). México: Instituto Chinoin, A. C.

Hágsater, E., \& Sánchez Saldaña, L (eds.). (2009). The genus Epidendrum, part 8, Species new \& old in Epidendrum, Icones Orchidacearum 12 (t. 12011300). México: Instituto Chinoin, A. C.

Hágsater, E., \& Sánchez Saldaña, L (eds.). (2010). The genus Epidendrum, part 9, Species new \& old in Epidendrum, Icones Orchidacearum 13 (t. 13011400). México: Instituto Chinoin, A. C.

Hágsater, E., \& Sánchez Saldaña, L (eds.). (2013). The genus Epidendrum, part 10, Species new \& old in Epidendrum, Icones Orchidacearum 14 (t. 14011500). México: Instituto Chinoin, A. C.

Hágsater, E., \& Sánchez Saldaña, L (eds.). (2015). The genus Epidendrum, part 11, Species new \& old in Epidendrum, Icones Orchidacearum 15(1) (t. 1501-1568). México: Instituto Chinoin, A. C.

Hágsater, E., \& Soto, M.A. (2005). Epidendrum. In A.M. Pridgeon, P.J. Cribb, M.W. Chase y F.N. Rasmussen (eds.), Genera Orchidacearum 4: Epidendroideae, part one (pp. 236-251). Cambridge: Oxford University Press.

Linnaeus, C. (1763). Species Plantarum, ed. 2 (p. 1347). London: Impenis direct. Laurentii Salvii.

Santiago, E., \& Hágsater, E. (2008). Epidendrum rigidiflorum. In E. Hágsater \& L. Sánchez S. (eds.), The Genus Epidendrum, Part 7, Icones Orchidacearum 11 (t. 1174). México: Instituto Chinoin, A. C.

Santiago, E., \& Hágsater, E. (2013). Epidendrum macrostachyum. In E. Hágsater \& L. Sánchez S. (eds.), The Genus Epidendrum, Part 10, Icones Orchidacearum 14 (t. 1454). México: Instituto Chinoin, A. C.
Santiago, E., \& Hágsater, E. (2015a). Epidendrum bangii. In E. Hágsater \& L. Sánchez S. (eds.), The Genus Epidendrum, Part 11, Icones Orchidacearum 15(1) (t. 1503). México: Instituto Chinoin, A. C.

Santiago, E., \& Hágsater, E. (2015b). Epidendrum coordinatum. In E. Hágsater \& L. Sánchez S. (eds.), The Genus Epidendrum, Part 11, Icones Orchidacearum 15(1). (t. 1514). México: Instituto Chinoin, A. C.

Santiago, E., \& Hágsater, E. (2015c). Epidendrum dermatanthum. In E. Hágsater \& L. Sánchez S. (eds.), The Genus Epidendrum, Part 11, Icones Orchidacearum 15(1) (t. 1519). México: Instituto Chinoin, A. C.

Santiago, E., \& Hágsater, E. (2015d). Epidendrum magnibracteum. In E. Hágsater \& L. Sánchez S. (eds.), The Genus Epidendrum, Part 11, Icones Orchidacearum 15(1) (t. 1538). México: Instituto Chinoin, A. C.

Santiago, E., \& Hágsater, E. (2015e), Epidendrum rostrigerum. In E. Hágsater \& L. Sánchez S. (eds.), The Genus Epidendrum, Part 11, Icones Orchidacearum 15(1) (t. 1556). México: Instituto Chinoin, A. C.

Sprague, T. A. (ed.). (1929). Proposals by British Botanists 46-96. International Botanical Congress, Cambridge (England), 1930, Nomenclature. London: Wyman \& sons, Ltd.

Szlachetko, D.L., Mytnik-Ejsmont, J., Romowicz, A. \& Margonska, H.B. (2006). Takulumena Szlach., A new genus of the subtribe Epidendrinae (Orchidaceae) from Ecuador. Die Orchidee, 57(3), 325-329.

Szlachetko, D.L., \& Kolanowska, M. (2014). The Genus Takulumena (Orchidaceae, Epidendreae) in Colombia. Wulfenia, 21, 63-81.

Williams, L.O. (1940). A new genus of the Orchidaceae from Central America. Botanical Museum Leaflets, 8, 148-151. 
